Journal of Advanced Research in Fluid Mechanics and Thermal Sciences

\title{
The Drying Rate of Chlorella pyrenoidosa Using an Oven in Bioethanol Production
}

\author{
Megawati ${ }^{1}{ }^{*}$, Astrilia Damayanti ${ }^{1}$, Putri Radenrara D. A. ${ }^{1}$, Pradnya Irene N. ${ }^{1}$, Khusnul Hotimah $^{1}$, \\ Yudha Satriawan ${ }^{1}$ \\ 1 Department of Chemical Engineering, Faculty of Engineering, Universitas Negeri Semarang, Indonesia
}

\section{ARTICLE INFO}

\section{Article history:}

Received 25 September 2020

Received in revised form 26 December 2020 Accepted 3 January 2021

Available online 5 February 2021

\section{Keywords:}

Chlorella pyrenoidosa; Drying rate;

Newton model; Oven; Page model

\section{ABSTRACT}

The production of bioethanol from microalgae goes through several stages, including cultivation, harvesting, drying, storage, and conversion to bioethanol. Nearly $40 \%$ of the total energy consumed in the bioethanol production from microalgae is from drying. This research aims to study the drying rate model of Chlorella pyrenoidosa using an oven. The drying is carried out at the temperatures of 50,60 , and $70{ }^{\circ} \mathrm{C}$. The initial moisture content of Chlorella pyrenoidosa was $317.798 \%$ dry weight. The results showed that at the temperatures of 50,60 , and $70^{\circ} \mathrm{C}$, the critical moisture content was $9.108,7.583$, and $6.93 \%$ dry weight, while the equilibrium moisture content was 3.172 , 3.158 , and $3.109 \%$ dry weight. The most optimal drying is at $70{ }^{\circ} \mathrm{C}$ and the drying rate gets faster as the temperature does too. The Page model is better at describing the drying rate of Chlorella pyrenoidosa using an oven than the Newton model. The drying speed constants (k) were $0.00056,0.00061$, and 0.00208 , at 50,60 , and $70{ }^{\circ} \mathrm{C}$, respectively.

\section{Introduction}

The rapid global economic growth as well as population growth have led to an increase in energy demand [1]. The energy needs at this time are mostly met from fossil energy, which is not renewable (unrenewable fuels) and its availability is very limited [2]. As a result of this scarcity, new and renewable energy sources is needed. Biofuels, like biodiesel and bioethanol, are the answer to this problem [3].

The microalgae have good prospects to be developed as a raw material for biofuels production. Some of the biofuels that can be produced from them are biodiesel, bioethanol, and biogas [4]. They have the ability to grow quickly and do not require a large area for production activities, do not compete with foodstuffs and can grow in sea water, fresh water, or wastewater [5].

\footnotetext{
* Corresponding author.

E-mail address: megawati@mail.unnes.ac.id

https://doi.org/10.37934/arfmts.80.1.128136
} 
The bioethanol production from the microalgae has several stages; they are cultivating and harvesting, drying, storing, and conversing to bioethanol [6]. Drying is process of removal water content. During drying process, heat is transferred from hot air to a product. Generally, on the same method, different product has their different drying rate and drying duration [7]. The drying process is important, because the energy conversion is very high. The post-harvested Chlorella pyrenoidosa contains $80-480 \%$ moisture content, so microalgae must be dried to $10 \%$ before being processed $[8,9]$. The drying process can also open the microalgae's cell walls $[10,11]$.

This research studied the equilibrium moisture content, critical moisture content, and drying rate of Chlorella pyrenoidosa using an oven. In the previous studies, the drying was carried out at the temperatures of $40,60,80,100,120$, and $140^{\circ} \mathrm{C}$. The result showed that the drying at 60 and $80^{\circ} \mathrm{C}$ can maintain the characteristics of the microalgae [12]. Using too low or too high temperature will affect the color, structure, carbohydrate and lipid composition [13]. Therefore, in this study, drying was carried out at temperatures of 50,60 , and $70{ }^{\circ} \mathrm{C}$. One important aspect in drying is the mathematical modeling of the drying process. There are several mathematical models for drying kinetics called Newton, Henderson and Pabis, Page, Modified Page, Logarithmic, Two-term Model, Two-term Exponential, Wang and Singh [14]. The purpose of mathematical modeling is to make it easier to choose the most suitable operating conditions. In addition, drying kinetics parameters can also be used to calculate drying speed, drying time, energy requirements, and designing drying systems on an industrial scale [8].

\section{Methodology}

The Chlorella pyrenoidosa slurry was obtained at UGO Plant Shop, Purworejo, Central Java. Before being used, it was stored in a refrigerator at $30^{\circ} \mathrm{C}$. Before the drying, it $( \pm 50 \mathrm{~g})$ was filtered using a filter paper (twice) and let stand for 15 minutes until a wet powder was obtained. The drying was done with $2 \mathrm{~g}$ of microalgae in a weighing bottle using an oven (Memmert, un 55). Every 5 minutes, the weight was observed using a digital scale (OHAUS PA214) and stopped after a constant weight was met. This drying was carried out at temperature variations of 50,60 and $70{ }^{\circ} \mathrm{C}$.

The moisture content analysis of Chlorella pyrenoidosa drying was calculated using Eq. (1), where $M_{t}$ is moisture content (\% dry weight), $W_{t}$ is weight at observed time $(\mathrm{g})$, and $W_{s}$ is dry weight $(\mathrm{g})$ [15].

$M_{t}=\frac{W_{t}-W_{s}}{W_{s}} x 100 \% \frac{\text { g total water }}{g \text { dry solid }}$

The equilibrium moisture content was identified when there was no change in the water content, also the critical moisture content was an average material moisture content at the end of the constant-rate-drying period, this period occurs before the equilibrium moisture content [10]. The equilibrium moisture content was calculated using Eq. (2), where $M_{e q}$ is the equilibrium moisture content (\% dry weight) and $W_{e q}$ is the equilibrium weight $(\mathrm{g})$ [15].

$M_{e q}=\frac{W_{e q}-W_{s}}{W_{s}} \times 100 \% \frac{g \text { total water }}{g \text { dry solid }}$

The main characteristic used to estimate drying performance is drying rate. The drying rate must be proportional to the difference in water content between the material to be dried and the equilibrium water content. The drying rate can be calculated using Eq. (3), where DR is the drying 
rate $\left(\mathrm{g} /\right.$ minute) and $W_{t+\Delta t}$ is the weight at $t+\Delta t(\mathrm{w} / \mathrm{w}$ dry), and $\Delta t$ is the difference in temperature (minute).

$D R=\frac{w_{t}-w_{t+\Delta t}}{\Delta t}$

Several studies have mathematically modeled the drying curve with a variety of different methods. The simplest exponential model (Newton's Model) is shown as in Eq. (4), where $M R=$ moisture ratio, $M_{t}=$ moisture content at observed time (\% dry weight), $M_{e q}=$ the equilibrium moisture content ( $\%$ dry weight), $M_{0}=$ initial moisture content ( $\%$ dry weight), and $k_{1}=$ drying constant. The exponential model has been modified to produce Page Model like Eq. (5), where $k_{2}=$ drying constant and $\mathrm{n}=$ Page constant [8].

$$
\begin{aligned}
& M R_{(c a l)}=\frac{M_{t}-M_{e q}}{M_{0}-M_{e q}}=\exp \left(-k_{1} t\right) \\
& M R_{(c a l)}=\frac{M_{t}-M_{e q}}{M_{0}-M_{e q}}=\exp \left(-k_{2} t^{n}\right)
\end{aligned}
$$

The value of each parameter $\left(k_{1}, k_{2}\right.$, and $\left.n\right)$ was tested, so that the calculation results of moisture ratio $(M R)$ approached the experimental data. For more systematic procedure, the differences in the calculation results and experimental data were calculated based on the minimum sum of squared error $(S S E)$ as well as the $R^{2}$ from Excel software. The $S S E$ equation is written as Eq. (6), where $M R_{(c a l)}=$ moisture ration calculated result, $M R_{(d)}=$ moisture ratio data, and $i=$ time .

$S S E=\sum_{i=1}^{i=n}\left(M R_{(c a l)}^{2}-M R_{(d)}^{2}\right)$

\section{Results}

\subsection{The Effect of Temperature on Chlorella pyrenoidosa Drying using an Oven}

The results of Chlorella pyrenoidosa drying at various temperatures $\left(50,60,70^{\circ} \mathrm{C}\right)$ can be seen in Figure 1. These curves have similar trends with drying result reported by Alimalbari et al., [7]. Alimalbari et al., [7] dried palm fruit using hot air-tray dryer with air temperature of 80 until $100{ }^{\circ} \mathrm{C}$. As the temperature gets higher, the moisture content drops dramatically which then become constant. On other hand, the moisture content reduces exponentially as the drying time increased. In this research, the initially moisture content of Chlorella pyrenoidosa was $317.798 \%$ dry weight. After 100 minutes, the moisture content dropped to $230.5,150.2$, and $79.6 \%$ dry weight for 50,60 , and $70{ }^{\circ} \mathrm{C}$, respectively. And after drying for 200 minutes it decreased to 163.2 and $18.8 \%$ dry weight for 50 and $60^{\circ} \mathrm{C}$, respectively. At this condition, for drying temperature of $70^{\circ} \mathrm{C}$, the moisture content of Chlorella pyrenoidosa was constant. However, for drying temperature of $60{ }^{\circ} \mathrm{C}$, the moisture content was almost constant. The best drying time at $70^{\circ} \mathrm{C}$ is 180 minutes, with moisture content of $1.671 \%$ dry weight.

Accordingly, the higher the temperature, the faster drying is [16]. This is also supported by previous research which stated that at the same time (10 minutes), the higher the power of microwave as energy source, the lower the moisture content would be [14]. Besides using an oven and microwave oven, drying of microalgae Neochloris conjucta using greenhouse drying has also been studied. The moisture content was initially $70.9 \% \mathrm{w} / \mathrm{w}$ dry weight and after $56 \mathrm{~h}$ it became $21.65 \% \mathrm{w} / \mathrm{w}$ dry weight [17]. 


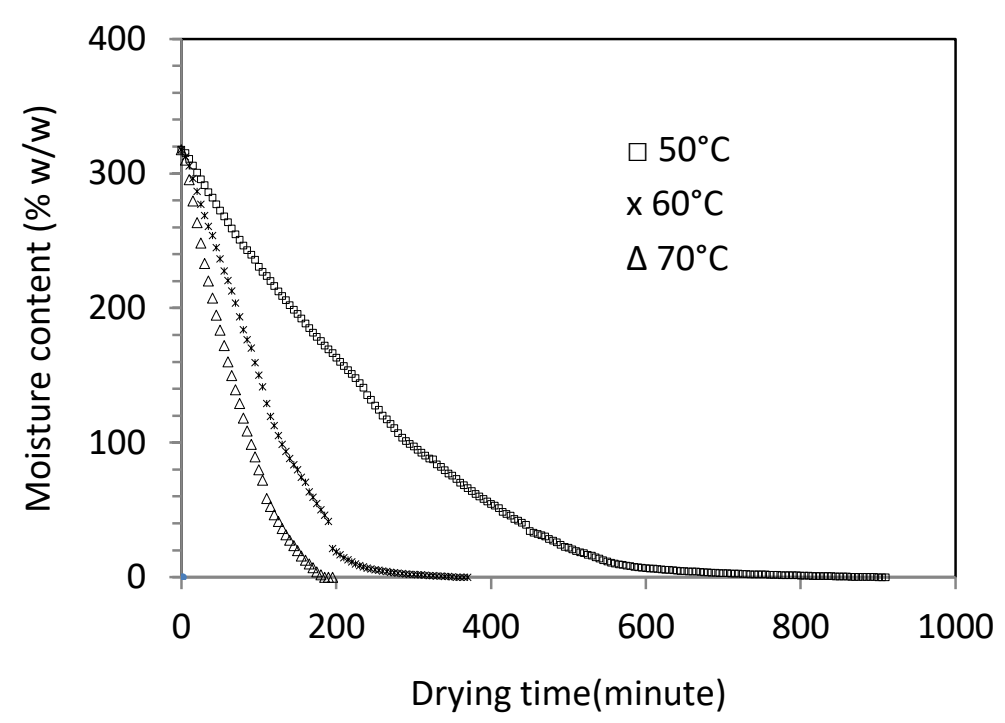

Fig. 1. The effect of temperature on Chlorella pyrenoidosa drying using an oven

The critical moisture content and equilibrium moisture content at each temperature variable is presented in Table 1. The values of the critical moisture content and equilibrium moisture content are different at various drying temperatures. In this research, the higher the drying temperature (50, 60 , and $70^{\circ} \mathrm{C}$ ), the smaller critical moisture content achieved. This is due to more available energy could evaporate water at the higher temperature.

Whereas for the equilibrium moisture content, in this Chlorella pyrenoidosa drying, the higher the temperature, the smaller the equilibrium moisture content value will be. The equilibrium moisture contents at drying temperatures of 50 and $60{ }^{\circ} \mathrm{C}$ are still close, in which the difference is only $0.44 \%$. However, the difference for temperatures of 60 and $70{ }^{\circ} \mathrm{C}$ is high, i.e. about $1.55 \%$. This indicate that the drying temperature of $70^{\circ} \mathrm{C}$ is very effective for Chlorella pyrenoidosa using an oven. This is in accordance with research conducted by Al Rey et al., [14] and Hosseinizand et al., [16]. They dried Chlorella vulgaris using oven and microwave, respectively $[14,16]$. It drying process of Chlorella vulgaris using an oven, at $40,60,80,100,120$, and $140^{\circ} \mathrm{C}$, the moisture content equilibriums dropped to $16.9 \pm 2.0,99 \pm 0.8,5.1 \pm 1.4,3,0 \pm 1.1,2.2 \pm 0.9$, and $1.3 \pm 0.3 \%$ dry weight, respectively [16]. This shows that the higher the temperature, Chlorella vulgaris has the drier the equilibrium moisture. In the study of Al Rey et al., [14], the process drying of Chlorella vulgaris was carried out using a microwave, the equilibrium moisture contents at a power variation of 300,600 , and $900 \mathrm{~W}$ were $0.23,0.07$, and $0.001 \%$ dry weight. This shows that at a higher power, equilibrium moisture content will dramatically decrease [14]. In the drying process using microwaves as an energy source, higher power indicates a higher temperature.

Table 1

The critical moisture content and equilibrium moisture content of Chlorella pyrenoidosa drying using an oven

\begin{tabular}{lll}
\hline Temperature $\left({ }^{\circ} \mathrm{C}\right)$ & $\begin{array}{l}\text { Critical Moisture Content } \\
\text { (\% dry weight) }\end{array}$ & $\begin{array}{l}\text { Equilibrium Moisture Content } \\
\text { (\% dry weight) }\end{array}$ \\
\hline 50 & 9.108 & 3.172 \\
60 & 7.583 & 3.158 \\
70 & 6.930 & 3.109 \\
\hline
\end{tabular}




\subsection{The Effect of Temperature on Chlorella pyrenoidosa Drying Rate using an Oven}

The drying rate calculation results can be seen in Figure 2 . These curves in the figure indicates that during the drying process, the drying rate is not the same. Theoretically, at the beginning of the process, the water on the surface will evaporate more easily, after which the water in the material will be difficult to get out [6]. Therefore, the drying rate will decrease during the drying. Recently, at the same drying times, the drying rate increases along with the increasing drying temperature [8]. Consequently, in this study, at 80 minutes, for 50,60 , and $70{ }^{\circ} \mathrm{C}$, the drying rate was $0.492,0.367$, and $0.233 \mathrm{~g} /$ minute, respectively. From the figure, it can be seen that the achieved optimum drying rate of Chlorella pyrenoidosa using an oven is at $70{ }^{\circ} \mathrm{C}$. Accordingly, at higher temperatures the relative humidity of the drying air was less compared to drying air at lower temperatures. Because of this, the higher temperature drying, the higher difference in the partial vapour pressure between material and the surrounding air environment will be. Hence, the moisture transfer rate was more with higher temperature drying air [7].

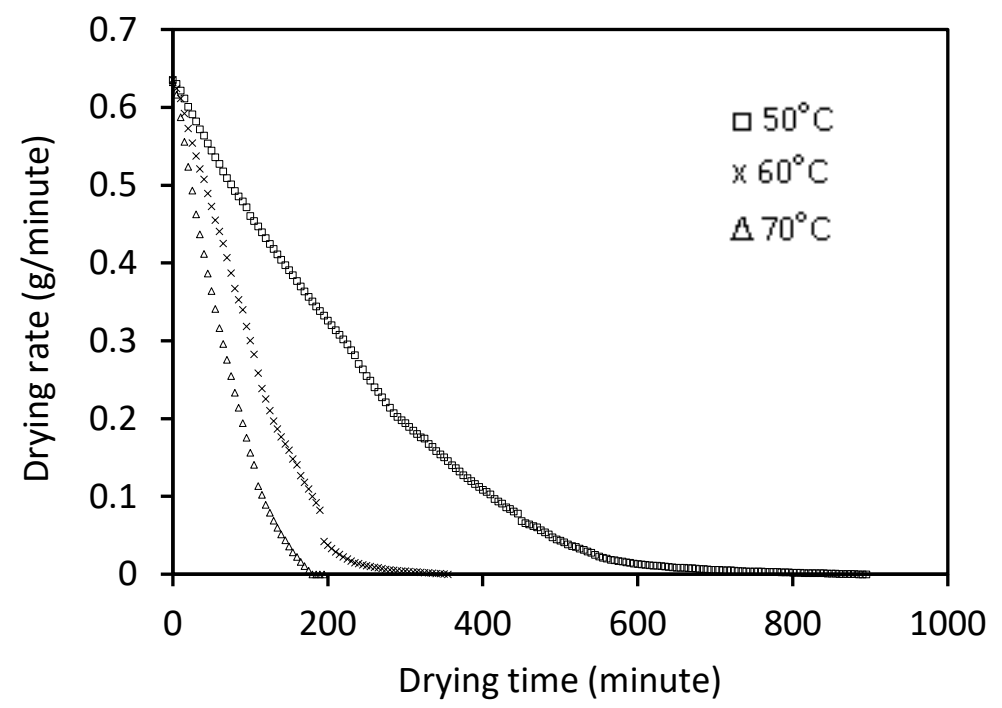

Fig. 2. The effect of temperature on the Chlorella pyrenoidosa drying rate using an oven

\subsection{The Drying Models of Chlorella pyrenoidosa using an Oven}

In this study, the drying models used are the Newton and Page Model. The calculation result for Newton Model can be seen in Figure 3. This figure shows that the Newton model cannot quantitatively describe the drying of microalgae Chlorella pyrenoidosa well. The values of the drying constant $\left(k_{1}\right)$ are about $0.0041,0.0092$, and 0.0141 /minute for the drying temperature of 50,60 , and $70{ }^{\circ} \mathrm{C}$. In addition, this model yielded the $S S E$ and $R^{2}$ values of 0.0038 and 0.8529 , respectively.

Figure 4 shows the drying kinetic using Page model. This figure indicates that the Page model is more suitable for the Chlorella pyrenoidosa drying, because it has a lower SSE value and higher $R^{2}$ compared to the Newton model, i.e. about 0.000428 and 0.856 , respectively. This is in accordance with research conducted by Viswanathan et al., [8]. In Page Model, the drying rate constants $\left(k_{2}\right)$ are $0.00056,0.00061$, and $0.00208 \mathrm{~min}^{-1}$ as well as the Page constants $(n)$ are 1.35, 1.56, and 1.43 at 50, 60 and $70{ }^{\circ} \mathrm{C}$, respectively. The data comparison and the calculation results of the moisture ratio using the Page Model is presented in Figure 5 to Figure 7. These figures show that the calculation 
results are close to the data, that is, approaching the diagonal line. Based on these three figures, the Page Model is suitable for Chlorella pyrenoidosa drying [18].

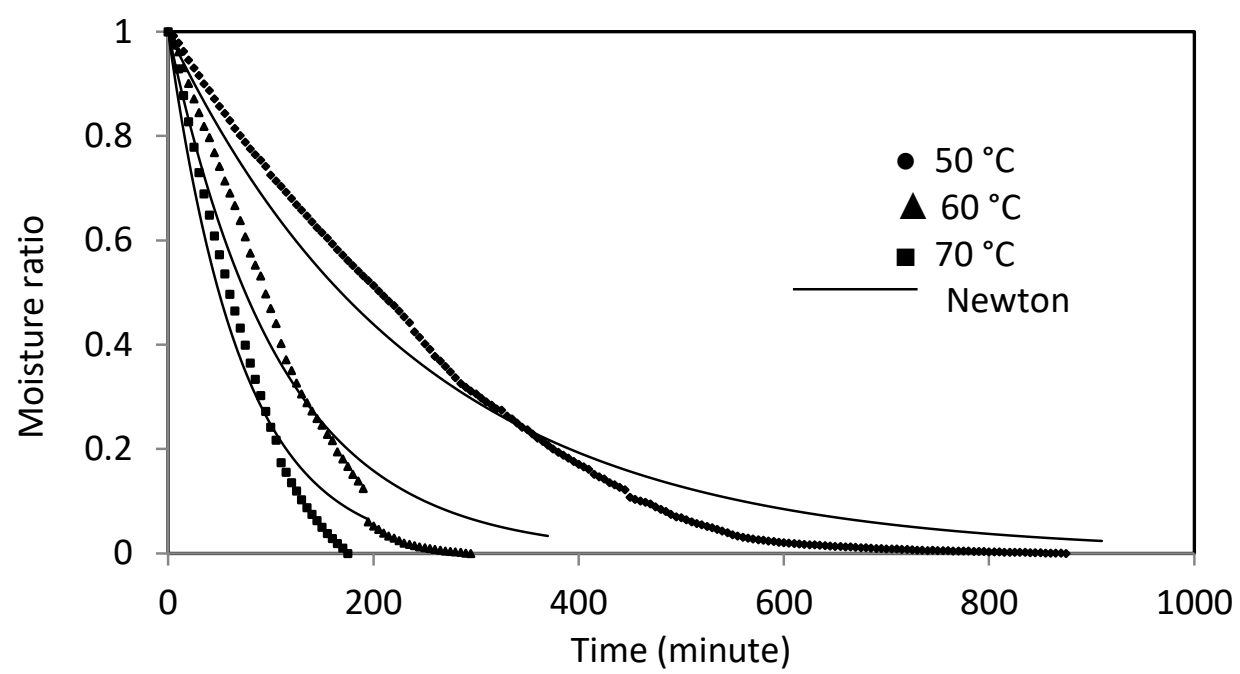

Fig. 3. The data comparison and moisture ratio calculation results of Chlorella pyrenoidosa drying using an oven (The Newton Model)

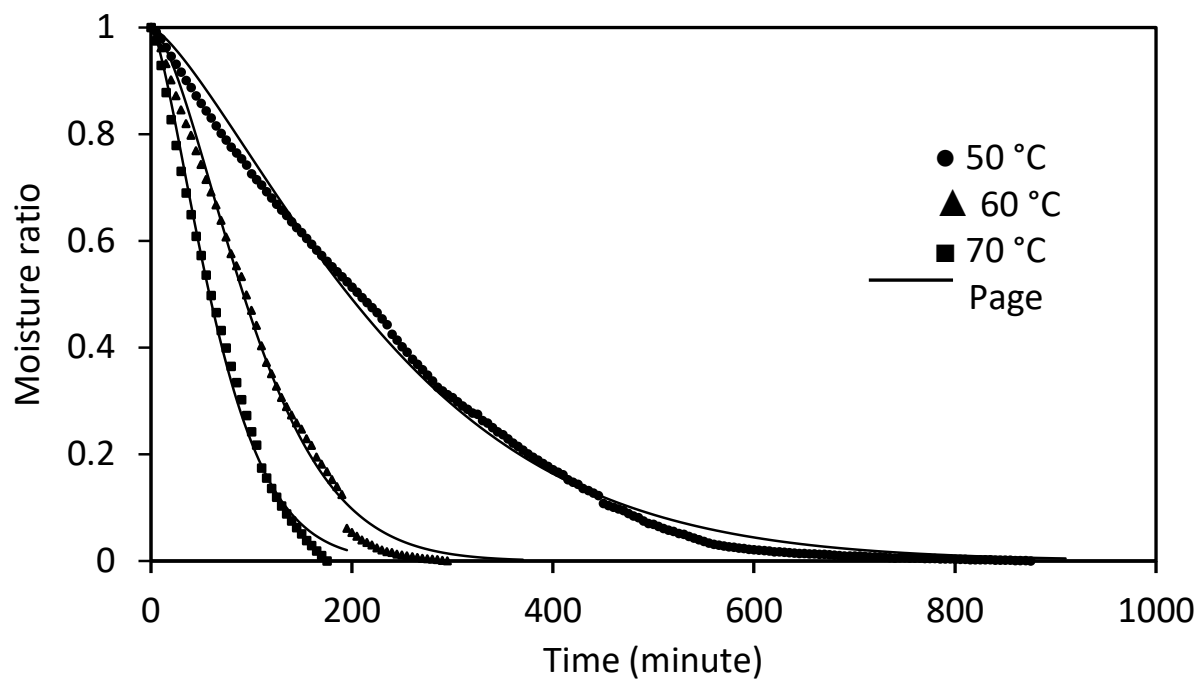

Fig. 4. The data comparison and moisture ratio calculation results of Chlorella pyrenoidosa drying using an oven (The Page Model) 


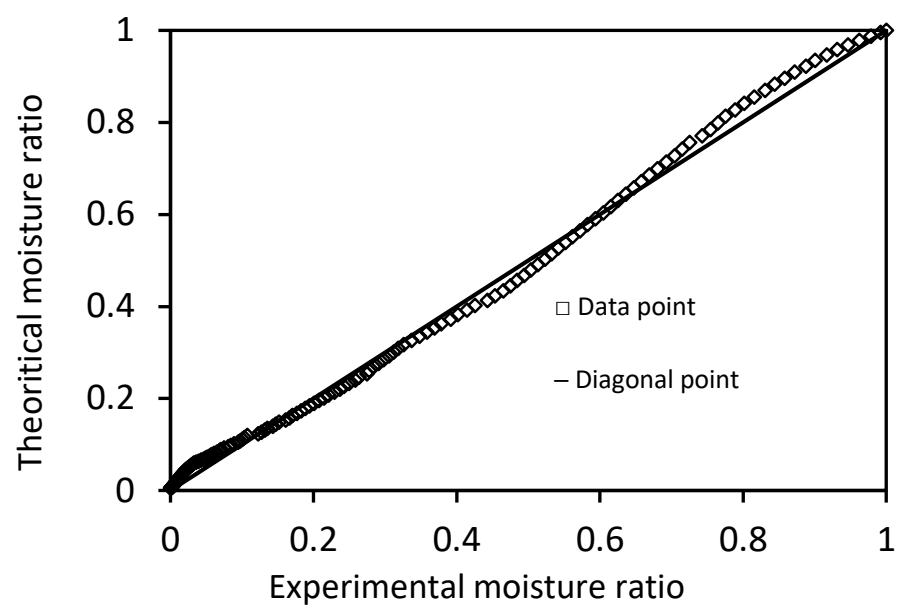

Fig. 5. The data comparison and moisture ratio calculation results of Chlorella pyrenoidosa drying using an oven (The Page Model at $50^{\circ} \mathrm{C}$ )

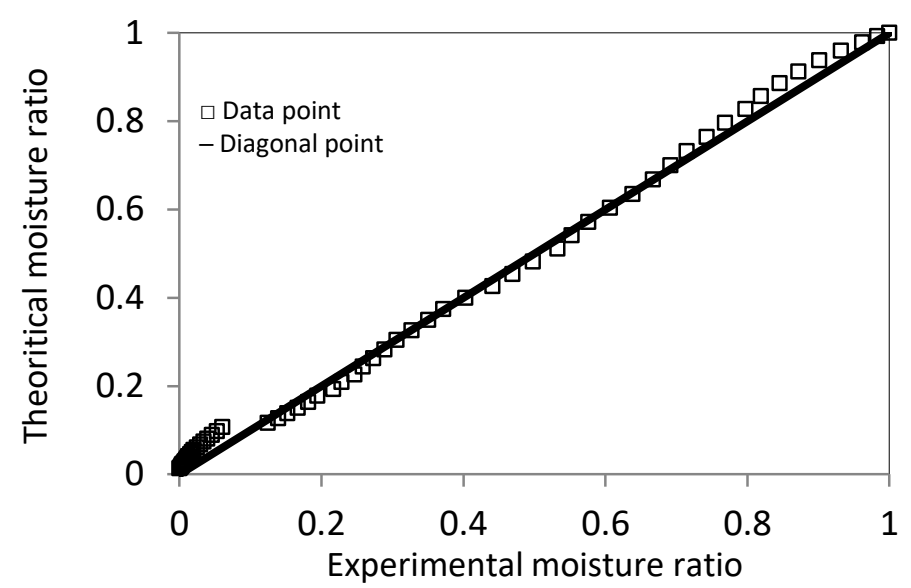

Fig. 6. The data comparison and moisture ratio calculation results of Chlorella pyrenoidosa drying using an oven (The Page Model at $60^{\circ} \mathrm{C}$ )

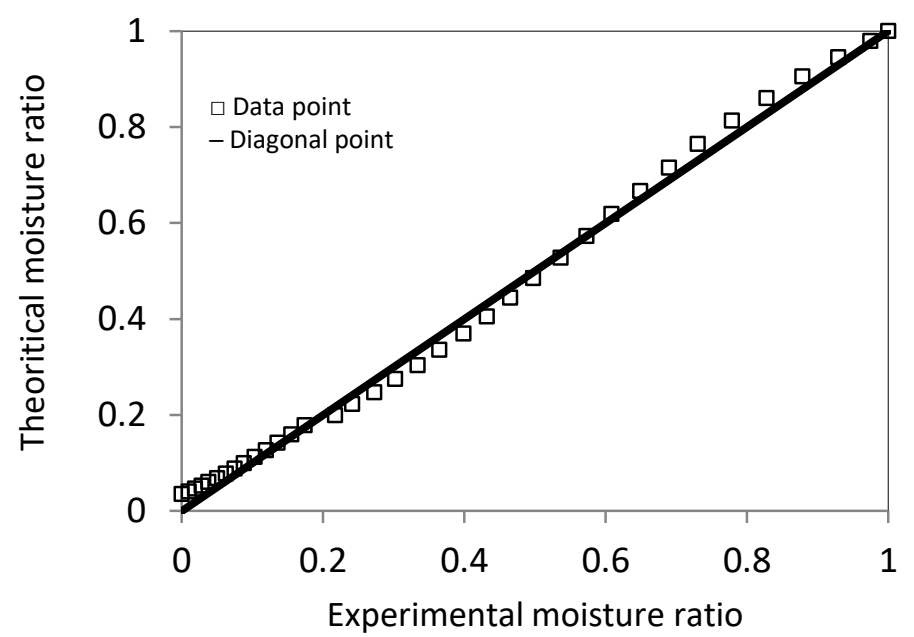

Fig. 7. The data comparison and moisture ratio calculation results of Chlorella pyrenoidosa drying using an oven (The Page Model at $70^{\circ} \mathrm{C}$ ) 


\section{Conclusions}

In the Chlorella pyrenoidosa drying, as the temperature gets higher, the moisture content lessening becomes faster and the moisture content equilibrium becomes smaller. The higher the temperature, the faster the drying speed is. The optimum drying rate of Chlorella pyrenoidosa is at $70{ }^{\circ} \mathrm{C}$ with a drying time of 180 minutes. The appropriate drying kinetic model for Chlorella pyrenoidosa is the Page Model with an $\mathrm{R}^{2}$ value of 0.856 and the drying rate constants are 0.00056 , 0.00061 , and $0.00208 \mathrm{~min}^{-1}$ for temperatures of 50,60 , and $70{ }^{\circ} \mathrm{C}$, respectively.

\section{Acknowledgement}

The author would like to thank Universitas Negeri Semarang and Indonesian Ministry of State for Research and Technology-Indonesian Directorate General of Higher Education (Kemenristek-Dikti) for research grant 2020.

\section{References}

[1] Rocha-Meneses, Lisandra, Merlin Raud, Kaja Orupõld, and Timo Kikas. "Potential of bioethanol production waste for methane recovery." Energy 173 (2019): 133-139.

https://doi.org/10.1016/i.energy.2019.02.073

[2] Huang, Lizhen, Guri Krigsvoll, Fred Johansen, Yongping Liu, and Xiaoling Zhang. "Carbon emission of global construction sector." Renewable and Sustainable Energy Reviews 81 (2018): 1906-1916.

https://doi.org/10.1016/i.rser.2017.06.001

[3] Bildirici, Melike E. "The effects of militarization on biofuel consumption and CO2 emission." Journal of Cleaner Production 152 (2017): 420-428.

https://doi.org/10.1016/i.jclepro.2017.03.103

[4] Alfonsín, V., R. Maceiras, and C. Gutiérrez. "Bioethanol production from industrial algae waste." Waste Management 87 (2019): 791-797.

https://doi.org/10.1016/i.wasman.2019.03.019

[5] Raheem, Abdul, Pepijn Prinsen, Arun K. Vuppaladadiyam, Ming Zhao, and Rafael Luque. "A review on sustainable microalgae based biofuel and bioenergy production: Recent developments." Journal of Cleaner Production 181 (2018): 42-59.

https://doi.org/10.1016/j.jclepro.2018.01.125

[6] Hosseinizand, Hasti, Shahab Sokhansanj, and C. Jim Lim. "Co-pelletization of microalgae Chlorella vulgaris and pine sawdust to produce solid fuels." Fuel Processing Technology 177 (2018): 129-139.

https://doi.org/10.1016/j.fuproc.2018.04.015

[7] Alimalbari, Ameen, Sherly Hanifarianty, Anil Kumar, Thanet Khomphet, Theera Eksomtramage, and Makatar Waehayee. "Effects of Pressed Palm Conditions on Acceleration of Palm Drying Rate and CPO Quality." Journal of Advanced Research in Fluid Mechanics and Thermal Sciences 55, no. 1 (2019): 12-19.

[8] Viswanathan, T., S. Mani, K. C. Das, S. Chinnasamy, A. Bhatnagar, R. K. Singh, and M. Singh. "Effect of cell rupturing methods on the drying characteristics and lipid compositions of microalgae." Bioresource Technology 126 (2012): 131-136.

https://doi.org/10.1016/i.biortech.2012.08.122

[9] Simioni, Taysnara, Marintho B. Quadri, and Roberto B. Derner. "Drying of Scenedesmus obliquus: Experimental and modeling study." Algal Research 39 (2019): 101428. https://doi.org/10.1016/j.algal.2019.101428

[10] Biz, Ana Paula, Lúcio Cardozo-Filho, and Everton Fernando Zanoelo. "Drying dynamics of microalgae (Chlorella pyrenoidosa) dispersion droplets." Chemical Engineering and Processing-Process Intensification 138 (2019): $41-48$. https://doi.org/10.1016/i.cep.2019.03.007

[11] Pohndorf, Ricardo S., Álisson S. Camara, Ana PQ Larrosa, Cláudio P. Pinheiro, Monique M. Strieder, and Luiz AA Pinto. "Production of lipids from microalgae Spirulina sp.: Influence of drying, cell disruption and extraction methods." Biomass and Bioenergy 93 (2016): 25-32. https://doi.org/10.1016/j.biombioe.2016.06.020

[12] Hossain, Md Nahian Bin, Joyanta Kumar Basu, and Mohammad Mamun. "The production of ethanol from microalgae Spirulina." Procedia Engineering 105 (2015): 733-738.

https://doi.org/10.1016/i.proeng.2015.05.064 
[13] Bagchi, Sourav Kumar, Pavuluri Srinivasa Rao, and Nirupama Mallick. "Development of an oven drying protocol to improve biodiesel production for an indigenous chlorophycean microalga Scenedesmus sp." Bioresource Technology 180 (2015): 207-213.

https://doi.org/10.1016/i.biortech.2014.12.092

[14] Al Rey, C. Villagracia, Andres Philip Mayol, Aristotle T. Ubando, Jose Bienvenido Manuel M. Biona, Nelson B. Arboleda, Melanie Y. David, Roy B. Tumlos et al. "Microwave drying characteristics of microalgae (Chlorella vulgaris) for biofuel production." Clean Technologies and Environmental Policy 18, no. 8 (2016): 2441-2451. https://doi.org/10.1007/s10098-016-1169-0

[15] Geankoplis, Christie J.. "Transport Processes and Unit Operations: PTR Prentice Hall." City, State, Country (1993).

[16] Hosseinizand, Hasti, Shahab Sokhansanj, and C. Jim Lim. "Studying the drying mechanism of microalgae Chlorella vulgaris and the optimum drying temperature to preserve quality characteristics." Drying Technology 36, no. 9 (2018): 1049-1060. https://doi.org/10.1080/07373937.2017.1369986

[17] Silva, Andreia FR, Helena Abreu, Artur Silva, and Susana M. Cardoso. "Effect of Oven-Drying on the Recovery of Valuable Compounds from Ulva rigida, Gracilaria sp. and Fucus vesiculosus." Marine Drugs 17, no. 2 (2019): 90. https://doi.org/10.3390/md17020090

[18] Ademiluyi, F. T., and M. F. N. Abowei. "Theoretical model for predicting moisture ratio during drying of spherical particles in a rotary dryer." Modelling and Simulation in Engineering 2013 (2013).

https://doi.org/10.1155/2013/491843 